\title{
Kateterablasjon for atrieflimmer
}

\section{Rasjonell pasientutvelgelse, omfattende ablasjonsstrategi og monitore- ring av kateterets trykkraft mot hjerteveggen kan gi bedre resultater og høyere sikkerhet ved kateterablasjon for atrieflimmer.}

Kateterablasjon med radiobølgeenergi er en moderne prosedyre som kan kurere atrieflimmer og dermed gi høyere livskvalitet. Prosedyrer ved kronisk atrieflimmer er spesielt krevende og utsetter pasienten for hyppigere komplikasjoner.

Mitt doktorarbeid består av tre delstudier som belyser betydningen av arytmivarighet, ny kateterteknologi og innvirkningen av flekainid på arytmisubstratet. Etter en oppfølgingstid på over tre år fant vi at ved en ablasjonsstrategi bestående av lungeveneisolasjon og kompleks fraksjonert elektrogram (CFE)-ablasjon, opprettholdt $58 \%$ av pasientene med kronisk atrieflimmer sinusrytme, og $22 \%$ opplevde bedring. Over halvparten av pasientene krevde mer enn én prosedyre. Kontinuerlig atrieflimmer i over fire år var en sterk negativ prediktor for klinisk suksess.

Vi fant også at store områder med CFE nødvendiggjorde en mer omfattende behandling. Flekainid gitt intravenøst reduserte utbredelsen av disse områdene med ca. $33 \%$. Administrering av flekainid kan således forkorte prosedyretiden.

Optimal trykkraft mellom kateter og hjertevev er viktig for å oppnå gode lesjoner og redusere tilbakefall av atrieflimmer. Med hjelp av nye ablasjonskatetre med innebygd trykkraftmåler fant vi at en trykkraft over $5 \mathrm{~g}$ fører til tilstrekkelige lesjoner, mens et trykk over $20 \mathrm{~g}$ gir økt risiko for komplikasjoner.

Funnene har betydning for pasientutvelgelse, ablasjonsstrategi og kateterteknologi for å oppnå sikrere prosedyrer.

de.bortoli.alessandro@gmail.com

\section{Alessandro De Bortoli}

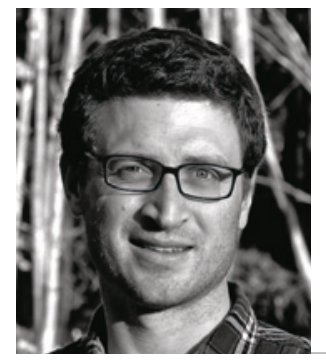

Alessandro De Bortoli. Foto: Marit Müller

Disputas

Alessandro De Bortoli disputerte for ph.d.graden ved Universitetet i Bergen 30.1. 2015. Tittelen på avhandlingen er: Improving the procedural safety and efficacy of radiofrequency catheter ablation for atrial fibrillation. Studies with special focus on non-paroxysmal atrial fibrillation.

\section{Frekvenskontroll av atrieflimmer}

\author{
Vi undersøkte frekvensreduserende medikamenter til behandling av \\ permanent atrieflimmer og fant at kalsiumblokkere for mange pasienter \\ fungerer bedre enn betablokkere, som brukes mest.
}

Det er minst 90000 personer med atrieflimmer i Norge. Frekvenskontroll er et godt etablert behandlingsalternativ for mange av disse, men det er fortsatt mangel på kunnskap om hvilke medikamenter som fungerer best til dette formålet.

I mitt doktorarbeid undersøkte vi 80 pasienter med permanent atrieflimmer uten systolisk hjertesvikt eller koronarsykdom. Gjennomsnittsalderen var 71 år, og omtrent to tredeler var menn. I en overkrysningsdesign ble pasientene i randomisert rekkefølge behandlet med to forskjellige betablokkere (metoprolol og karvedilol) og to forskjellige kalsiumblokkere (diltiazem og verapamil). Kalsiumblokkerne var like effektive som betablokkerne i å redusere hjertefrekvensen. Dessuten ble atrieflim- merrelaterte symptomer redusert av kalsiumblokkerne, men ikke av betablokkerne. Vi fant også at pasientene fikk dårligere fysisk yteevne og økt nivå av biomarkøren NT-proBNP under behandling med betablokkere, mens yteevnen var bevart og nivået av NT-proBNP redusert under behandling med kalsiumblokkere. Troponinnivået ble redusert med alle fire behandlingene.

Disse funnene tyder på at kalsiumblokkere oftere bør vurderes for frekvenskontroll hos pasienter med permanent atrieflimmer uten annen hjertesykdom. Resultatene har betydning for en stor del av dem som har atrieflimmer.

\section{Sara Reinvik Ulimoen}

sara.reinvik.ulimoen@vestreviken.no

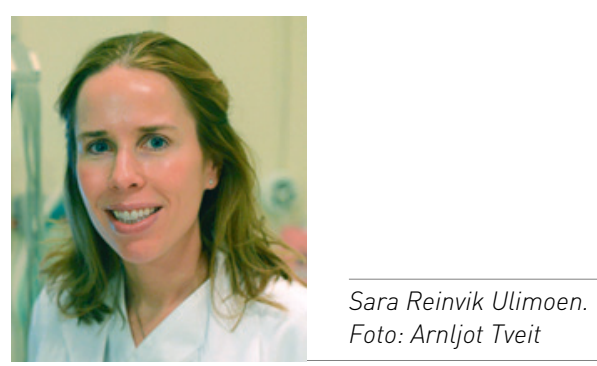

Disputas

Sara Reinvik Ulimoen disputerte for ph.d.graden ved Universitetet i Oslo 13.1. 2015. Tittelen på avhandlingen er: Rate control in atrial fibrilation - impact of rate-reducing drugs on ventricular rate, arrhythmia-related symptoms, exercise capacity and biomarkers. 